\title{
Clinical features, socio-demographic profile and ultrasound findings in women with endometriosis symptoms
}

\author{
Características clínicas, perfil sociodemográfico e achados ecográficos \\ em mulheres com sintomas de endometriose
}

\author{
Jorge Gilmar Amaral de Oliveira ${ }^{1}$ (D), Vanessa Bonfada ${ }^{1}(\mathbb{D})$, Michele Ferraz Figueiró $^{2}(\mathbb{D}$, \\ Tatiana Mugnol $^{3}\left(\mathbb{D}\right.$, Janice de Fátima Pavan Zanella ${ }^{1,3}\left(\mathbb{D}\right.$, Janaina Coser ${ }^{1,3}(\mathbb{D})$ \\ ${ }^{1}$ University of Cruz Alta / Regional University of the Northwest of the State of Rio Grande do Sul, Post-Graduate Program in Comprehensive Health Care UNICRUZ / \\ UNIJUI. Cruz Alta / ljuí, RS, Brazil \\ ${ }^{2}$ University of Cruz Alta, Applied Statistics Center. Cruz Alta, RS, Brazil. \\ ${ }^{3}$ University of Cruz Alta, Course of Biomedicine. Cruz Alta, RS, Brazil.
}

How to cite this article:

Oliveira JGA, Bonfada V, Figueiró MF, Mugnol T, Zanella JFP, Coser J. Clinical features, socio-demographic profile and ultrasound findings in women with endometriosis symptoms. Sci Med. 2018;28(4):ID30496 DOI: 10.15448/1980-6108.2018.4.30496

\section{ABSTRACT}

AIMS: To describe clinical and socio-demographic features, as well as transvaginal ultrasound results, of women with endometriosis symptoms METHODS: A prospective cross-sectional study included patients who had at least one of the following symptoms: dyspareunia, dysmenorrhea, chronic pelvic pain, infertility, and urinary or bowel cyclic symptoms. The sample comprised women treated in a private gynecology clinic located in a small city in southern Brazil, from March to November 2016. All the participants, after signed an informed consent, were subjected to clinical anamnesis, transvaginal ultrasound with bowel preparation, and examination for the CA-125 antigen serum level. Association between two qualitative variables was assessed through Pearson's Chi-Square or Fisher's exact tests. Mean values of quantitative variables were compared through the two-tailed Student's t-test for independent samples. Significance level was set as $\mathrm{p}<0.05$.

RESULTS: A total of 85 women, aged 18-49 years, participated in the study. Most were married (75.3\%), with children (51.8\%), showed no family history of endometriosis $(89.4 \%)$, had no knowledge about endometriosis (77.6\%) and completed high school (43.5\%). Ultrasound findings suggested endometriosis in 25 (29.4\%) women. Dysmenorrhea was the most prevalent symptom (88.2\%), followed by dyspareunia $(61.2 \%)$. In comparison to those without ultrasound signs, the patients whose ultrasound findings suggested endometriosis had an older age $(37.16 \pm 6.83$ years $v$ s. $30.37 \pm 6.80$ years, $\mathrm{p}<0.001)$ and a longer duration of symptoms $(9.06 \pm 6.49$ years $v s .5 .27 \pm 4.79$ years, $\mathrm{p}=0.004)$. In addition, they presented higher mean serum CA-125 antigen levels $(50.07 \pm 54.05 \mathrm{U} / \mathrm{mL} v s .17 .71 \pm 14.09 \mathrm{U} / \mathrm{mL}$, $\mathrm{p}=0.011)$. Endometriosiscompatible lesions were mainly found in the ovaries $(60 \%)$ and in the rectosigmoid region $(52 \%)$. The disease was confirmed in the nine cases that were subjected to videolaparoscopy.

CONCLUSIONS: Transvaginal ultrasound confirmed endometriosis in about one third of symptomatic patients, who were older, had symptoms for a longer time, and had higher serum CA-125 antigen levels in comparison to those without endometriosis diagnosis based on transvaginal ultrasound. Ovaries and rectosigmoid region were the sites with the highest frequency of ultrasound signs of endometriosis.

KEYWORDS: endometriosis; diagnostic imaging; CA-125 antigen; female urogenital diseases; health profile.

\section{RESUMO}

OBJETIVOS: Descrever características clínicas e sociodemográficas, bem como resultados de ultrassonografia transvaginal, de mulheres com sintomas de endometriose.

MÉTODOS: Um estudo transversal prospectivo incluiu pacientes que apresentaram pelo menos um dos seguintes sintomas: dispareunia, dismenorreia, dor pélvica crônica, infertilidade e sintomas urinários ou intestinais cíclicos. A amostra foi composta por mulheres atendidas em clínica privada de ginecologia, localizada em uma pequena cidade do sul do Brasil, de março a novembro de 2016. Todas as participantes, após assinatura do termo de consentimento livre e esclarecido, foram submetidas a anamnese clínica, ultrassonografia transvaginal com preparo intestinal e análise do nível sérico do antígeno CA-125. A associação entre duas variáveis qualitativas foi avaliada pelos testes Qui-Quadrado de Pearson ou Exato de Fisher. Os valores médios das variáveis quantitativas foram comparados através do teste t de Student bicaudal para amostras independentes. O nível de significância foi estabelecido como $\mathrm{p}<0,05$.

RESULTADOS: Um total de 85 mulheres, com idade entre 18 e 49 anos, participou do estudo. A maioria era casada (75,3\%), com filhos (51,8\%), não apresentava história familiar de endometriose $(89,4 \%)$, não tinha conhecimento sobre endometriose $(77,6 \%)$ e tinha ensino médio completo $(43,5 \%)$. Achados ultrassonográficos sugeriram endometriose em $25(29,4 \%)$ mulheres. A dismenorreia foi o sintoma mais prevalente $(88,2 \%)$, seguida pela dispareunia $(61,2 \%)$. Em comparação com aquelas sem sinais ultrassonográficos, as pacientes cujos achados 
ultrassonográficos sugeriram endometriose tinham idade mais avançada $(37,16 \pm 6,83$ anos $v s .30,37 \pm 6,8$ anos, $\mathrm{p}<0,001)$ e maior duração dos sintomas $(9,06 \pm 6,49$ anos $v s .5,27 \pm 4,79$ anos, $\mathrm{p}=0,004)$. Além disso, apresentaram níveis séricos de antígeno CA-125 mais elevados $(50,07 \pm 54,05 \mathrm{U} / \mathrm{mL}$ vs. 17,71 $\pm 14,09 \mathrm{U} / \mathrm{mL}, \mathrm{p}=0,011)$. Lesões compatíveis com endometriose foram encontradas principalmente nos ovários $(60 \%)$ e na região retossigmoide (52\%). A doença foi confirmada nos nove casos que foram submetidos a videolaparoscopia.

CONCLUSÕES: A ultrassonografia transvaginal confirmou a endometriose em cerca de um terço das pacientes sintomáticas, que eram mais velhas, apresentavam sintomas por mais tempo e tinham níveis mais altos de antígeno CA-125 sérico, em comparação àquelas sem diagnóstico de endometriose com base na ultrassonografia transvaginal. Ovários e região retossigmoide foram os locais com maior frequência de sinais ultrassonográficos de endometriose.

DESCRITORES: endometriose; diagnóstico por imagem; antígeno CA-125; doenças urogenitais femininas; perfil de saúde.

Abbreviation: TVUS, transvaginal ultrasound.

\section{INTRODUCTION}

Endometriosis is a chronic, inflammatory, estrogendependent disease, characterized by the presence of endometrial tissue outside the uterine cavity. When there is more than $5 \mathrm{~mm}$-deep infiltration in the peritoneal surface, the disease is called deep pelvic endometriosis. The deep pelvic endometriosis may affect adjacent organs such as uterine ligaments, intestine, bladder and/or ureters [1].

Women affected by this disease present a variable clinical picture, and may be asymptomatic. Symptoms (gynecological or not) are associated with the lesion site and mainly comprise infertility, dysmenorrhea, pelvic pain, dyspareunia, and urinary and bowel disorders [2]. Quality of life of women presenting delayed diagnosis of endometriosis is diminished because the symptoms affect their social, family, sexual, affective and professional life [3].

Definitive diagnosis of endometriosis is done through surgical intervention, preferably videolaparoscopy. However, non-invasive methods may help identifying the disease and avoiding its delayed diagnosis. Studies have shown that transvaginal ultrasound (TVUS) is a useful tool for investigation of endometriosis; it is recommended as a first-line method to assess patients with suspected deep pelvic endometriosis, as well as in surgery planning. Biomarkers such as CA-125 serum level may also enable the non-invasive diagnosis of the disease [4-10].

In Brazil, studies that investigate endometriosis are concentrated in large centers and metropolitan areas, a fact that restricts access to treatment and knowledge of the representative profile of the population that does not reside in these locations. Thus, studies on endometriosis should be encouraged also in the small cities and the countryside, in order to know the characteristics of affected women and to better target health interventions. Therefore, the objective of this study was to evaluate women with symptoms of endometriosis treated at a gynecological clinic in southern Brazil and to describe their clinical and socio-demographic characteristics as well as the ultrasonographic associated findings.

\section{METHODS}

The present study was submitted to the Ethics and Research Committee of Cruz Alta University, and was approved through Opinion numbers 1.377 .518 and 1.554.278. All the participants received and signed the free and informed consent form.

The present research was designed as a crosssectional, prospective study comprising women treated in a private gynecology clinic located in Ijuí city, southern Brazil, from March to November 2016. The municipality where the study was carried out has 83,173 inhabitants, presents great ethnic diversity due to European immigration, and has subtropical climate and vegetation [11].

Women presenting at least one of the following symptoms were included in the study: dyspareunia, dysmenorrhea, chronic pelvic pain, infertility, and urinary or bowel cyclic symptoms. Patients who had no clinical suspicion of endometriosis and those who did not agree to participate in the study were not included.

Socio-demographic (age, marital status, schooling, children) and clinical data (symptoms, infertility, family history of endometriosis and patients' knowledge about the disease), as well as information about CA-125 serum levels (normal reference value up to $35 \mathrm{U} / \mathrm{ml}$ ), were collected from patients' medical charts. Women were questioned about endometriosis during clinical anamnesis.

All participants were subjected to TVUS with bowel preparation. The examination was conducted by a single experienced professional, with the aid of an ultrasound device Model UGEO H60 Smart Samsung ${ }^{\circledR}$ 
(manufacturing year 2015, Korea), using sectoral and intracavitary multi-frequency transducers (vaginal and rectal) with color Doppler and color Power Angio ${ }^{\mathrm{TM}}$ imaging.

The adopted TVUS technique was based on procedures described by the International Deep Endometriosis Analysis group [12]. The first examination step lied on assessing the uterus and its adnexa through the supra-pubic route, after the bladder and the kidneys were examined in order to rule out hydronephrosis. The second step lied on using the vaginal transducer to check uterine and ovarian mobility, which were classified as normal, reduced or fixed; sonographic signs of adenomyosis were also assessed. The third step comprised investigating markers such as local sensitivity and ovarian fixation. Subsequently, the "sliding sign" (the anterior rectal wall slides free from the posterior uterine cervix and vaginal walls) was assessed. The fourth step comprised the study of hypoechogenic nodules or irregularities in the anterior (bladder, ureters, and vesicouterine pouch) and posterior compartments (Douglas' pouch, ligaments, uterine torus, vaginal fornix and rectosigmoid region). All the examinations were performed with bowel preparation - low-residue diet and an oral laxative the day before, and enema one hour before the examination. Deep endometriosis implants were suspected from the presence of hypoechoic linear thickening or nodules/masses with or without regular contours, as described by Guerriero et al [13]. Followup was performed by the attending physicians, and videolaparoscopy, clinical treatment, laparotomy, hysterectomy or prenatal care might be indicated.

Statistical analysis was performed in the IBM SPSS 22 software. Qualitative variables were described as absolute and percent frequencies, whereas quantitative variables were described through descriptive measures (minimum, maximum, mean and standard deviation). Association between two qualitative variables was assessed through Pearson's Chi-Square or Fisher's exact tests. Mean values of variables such as age, symptoms duration and CA-125 serum levels in patients whose TVUS results showed endometriosis signs were compared through two-tailed Student's t-test for independent samples. All the analyses took into consideration a 5\% significance level.

\section{RESULTS}

Eighty-five women were included in the study. Of these, 25 (29.4\%) presented ultrasound findings suggestive of endometriosis, according to the criteria described in the methodology. These patients age ranged from 18 to 49 years and there was a statistically significant difference between the mean age of women with ultrasound confirmed endometriosis $(37.16 \pm 6.83$ years) and of those who did not present any evidence of the disease at TVUS $(30.37 \pm 6.80$ years $),(p<0.001)$. Most patients were married $(75.3 \%)$, with children $(51.8 \%)$, and completed high school (43.5\%). These characteristics did not show significant association with ultrasound findings suggesting endometriosis, according to the Pearson's Chi-square test (Table 1).

Table 1. Socio-demographic features of 85 women with clinical symptoms of endometriosis, according to transvaginal ultrasound results.

\begin{tabular}{|c|c|c|c|c|}
\hline \multirow[b]{2}{*}{$\begin{array}{l}\text { Socio-demographic } \\
\text { feature }\end{array}$} & \multicolumn{4}{|c|}{ Endometriosis at transvaginal ultrasound } \\
\hline & $\begin{array}{c}\text { Total } \\
(n=85) \\
N(\%)\end{array}$ & $\begin{array}{c}\text { No } \\
(n=60) \\
N(\%)\end{array}$ & $\begin{array}{c}\text { Yes } \\
(n=25) \\
N(\%)\end{array}$ & P-value \\
\hline $\begin{array}{l}\text { Marital Status } \\
\text { Married } \\
\text { Single } \\
\text { Divorced }\end{array}$ & $\begin{array}{c}64(75.3) \\
17(20.0) \\
4(4.7)\end{array}$ & $\begin{array}{c}45(52.9) \\
14(16.5) \\
1(1.2)\end{array}$ & $\begin{aligned} 19 & (22.4) \\
3 & (3.5) \\
3 & (3.5)\end{aligned}$ & $0.07^{\mathrm{a}}$ \\
\hline $\begin{array}{l}\text { Children } \\
\text { No } \\
\text { Yes }\end{array}$ & $\begin{array}{l}41(48.2) \\
44(51.8)\end{array}$ & $\begin{array}{l}31(36.5) \\
29(34.1)\end{array}$ & $\begin{array}{l}10(11.8) \\
15(17.6)\end{array}$ & $0.229^{a}$ \\
\hline $\begin{array}{l}\text { Schooling } \\
\text { Elementary School } \\
\text { Secondary School } \\
\text { Higher Education }\end{array}$ & $\begin{array}{l}24(28.2) \\
37(43.5) \\
24(28.2)\end{array}$ & $\begin{array}{l}14(16.5) \\
27(31.8) \\
19(22.4)\end{array}$ & $\begin{array}{c}10(11.8) \\
10(11.8) \\
5(5.9)\end{array}$ & $0.261^{\mathrm{a}}$ \\
\hline
\end{tabular}

a Pearson's Chi-Square test at $\alpha=5 \%$.

With respect to clinical aspects, most patients showed no family history of endometriosis (89.4\%) and had no knowledge about the disease (77.6\%). Dysmenorrhea was the most prevalent symptom $(88.2 \%)$, followed by dyspareunia $(61.2 \%)$. Mean duration of symptoms showed statistically significant difference between women with endometriosis and those who did not present ultrasound findings suggesting the disease $(p=0.004)$. The mean CA-125 serum concentration was also significantly higher among women with endometriosis $(50.07 \pm 54.05 \mathrm{U} / \mathrm{mL}$, $\mathrm{p}=0.011$ ). Other clinical features did not show association with ultrasound findings suggesting endometriosis (Table 2).

Women whose ultrasound findings suggested endometriosis showed mainly endometrioma-type lesions $(60 \%)$, followed by lesions in the rectosigmoid $(52 \%)$ and retrocervical regions (28\%) (Table 3 ).

Among the 25 women with TVUS results suggestive of endometriosis, 11 (44\%) patients returned to the attending physician and were lost to follow-up; $9(36 \%)$ women were submitted to videolaparoscopy; two women $(8 \%)$ received clinical treatment; two $(8 \%)$ 
women were pregnant and were referred to prenatal care; and one woman $(4 \%)$ was submitted to hysterectomy. Endometriosis was confirmed in all women submitted to videolaparoscopy. No woman without evidence of endometriosis in the TVUS was submitted to videolaparoscopy.

Table 2. Clinical features of 85 women with symptoms of endometriosis, according to transvaginal ultrasound results.

\begin{tabular}{|c|c|c|c|c|}
\hline \multirow[b]{2}{*}{ Characteristic } & \multicolumn{4}{|c|}{ Endometriosis at transvaginal ultrasound } \\
\hline & $\begin{array}{c}\text { Total } \\
(\mathbf{n = 8 5}) \\
\mathbf{N}(\%)\end{array}$ & $\begin{array}{c}\text { No } \\
(n=60) \\
N(\%)\end{array}$ & $\begin{array}{c}\text { Yes } \\
(n=25) \\
N(\%)\end{array}$ & $p$-value \\
\hline $\begin{array}{l}\text { Family history of } \\
\text { endometriosis } \\
\text { No } \\
\text { Yes }\end{array}$ & $\begin{array}{l}76(89.4) \\
9(10.6)\end{array}$ & $\begin{array}{c}54(63.5) \\
6(7.1)\end{array}$ & $\begin{aligned} 22 & (25.9) \\
3 & (3.5)\end{aligned}$ & $0.527^{b}$ \\
\hline $\begin{array}{l}\text { Knowledge about } \\
\text { endometriosis } \\
\text { No } \\
\text { Yes }\end{array}$ & $\begin{array}{l}66(77.6) \\
19(22.4)\end{array}$ & $\begin{array}{l}50(58.8) \\
10(11.8)\end{array}$ & $\begin{array}{c}16(18.8) \\
9(10.6)\end{array}$ & $0.051^{b}$ \\
\hline $\begin{array}{l}\text { Chronic pelvic pain } \\
\text { No } \\
\text { Yes }\end{array}$ & $\begin{array}{l}59(69.4) \\
26(30.6)\end{array}$ & $\begin{array}{l}43(50.6) \\
17(20.0)\end{array}$ & $\begin{array}{c}16(18.8) \\
9(10.6)\end{array}$ & $0.485^{a}$ \\
\hline $\begin{array}{l}\text { Dysmenorrhea } \\
\text { No } \\
\text { Yes }\end{array}$ & $\begin{array}{l}10(11.8) \\
75(88.2)\end{array}$ & $\begin{array}{c}8(9.4) \\
52(61.2)\end{array}$ & $\begin{array}{c}2(2.4) \\
23(27.1)\end{array}$ & $0.388^{b}$ \\
\hline $\begin{array}{l}\text { Dyspareunia } \\
\text { No } \\
\text { Yes }\end{array}$ & $\begin{array}{l}33(38.8) \\
52(61.2)\end{array}$ & $\begin{array}{l}23(27.1) \\
37(43.5)\end{array}$ & $\begin{array}{l}10(11.8) \\
15(17.6)\end{array}$ & $0.886^{a}$ \\
\hline $\begin{array}{l}\text { Urinary disorders } \\
\text { No } \\
\text { Yes }\end{array}$ & $\begin{array}{l}71(83.5) \\
14(16.5)\end{array}$ & $\begin{array}{l}51(60.0) \\
9(10.6)\end{array}$ & $\begin{aligned} 20 & (23.5) \\
5 & (5.9)\end{aligned}$ & $0.392^{b}$ \\
\hline $\begin{array}{l}\text { Bowel disorders } \\
\text { No } \\
\text { Yes }\end{array}$ & $\begin{array}{l}43(50.6) \\
42(49.4)\end{array}$ & $\begin{array}{l}30(35.3) \\
30(35.3)\end{array}$ & $\begin{array}{l}13(15.3) \\
12(14.1)\end{array}$ & $0.528^{b}$ \\
\hline $\begin{array}{l}\text { Infertility } \\
\text { Does not know } \\
\text { No } \\
\text { Yes }\end{array}$ & $\begin{array}{c}27(31.8) \\
49(57.6) \\
9(10.6)\end{array}$ & $\begin{array}{c}24(28.2) \\
33(38.8) \\
3(3.5)\end{array}$ & $\begin{aligned} & (3.5) \\
16 & (18.8) \\
6 & (7.1)\end{aligned}$ & $0.05^{\mathrm{a}}$ \\
\hline $\begin{array}{l}\text { Symptom duration } \\
\text { (years) }\end{array}$ & $6.36(5.57)$ & $5.27(4.79)$ & $9.06(6.49)$ & $0.004^{c}$ \\
\hline CA-125 (U/ml) & $\begin{array}{c}27.88 \\
(35.40)\end{array}$ & $\begin{array}{c}17.71 \\
(14.09)\end{array}$ & $\begin{array}{c}50.07 \\
(54.05)\end{array}$ & $0.011^{c}$ \\
\hline
\end{tabular}

a Pearson's Chi-Square test at $\alpha=5 \%$.

bisher's exact test at $\alpha=5 \%$.

'Mean (standard deviation); Student's t-test for independent samples at $\alpha=5 \%$.

Table 3. Sites of endometriosis findings according to transvaginal ultrasound in 25 women with clinical symptoms and transvaginal ultrasound findings suggesting endometriosis.

\begin{tabular}{lc}
\hline Lesion site & $\mathbf{n}(\%)^{*}$ \\
Ovary (endometrioma) & $15(60.0)$ \\
Rectosigmoid region & $13(52.0)$ \\
Retrocervical region & $7(28.0)$ \\
Myometrium & $2(8.0)$ \\
Round ligament & $2(8.0)$ \\
Broad ligament & $1(4.0)$ \\
Uterosacral ligament & $1(4.0)$ \\
Recto-uterine region & $1(4.0)$ \\
Bladder & $1(4.0)$ \\
\hline
\end{tabular}

*Some patients had lesions in more than one site.

\section{DISCUSSION}

According to Ferrero et al. [14], general practitioners should pay attention to symptoms reported by their patients, as well as investigate endometriosis in case of suspected clinical picture, in order to avoid diagnosis delay. Dysmenorrhea (88.2\%) was the most prevalent symptom recorded in the current study, and was followed by dyspareunia (61.2\%). Similar to the current findings, other studies also recorded that dysmenorrhea was the main complaint reported by women assisted in reference services for endometriosis treatment [15-17].

Cardoso et al. [19] recommend performing the examination with bowel preparation to help visualizing deeper endometriosis such as that located in the retrocervical region or in the rectovaginal septum. According to Gonçalves et al. [20], bowel preparation helps to identify intestinal lesions, since it eliminates or decreases the amount of intestinal gases and wastes. Thus, it allows visualizing the affected layers and better differentiating the posterior vaginal, rectovaginal septum and rectal walls [20]. TVUS conducted with bowel preparation was the technique adopted in the current study to assess women with clinical suspicion of endometriosis. Ovaries and rectosigmoid region were the most affected sites.

Endometriomas are endometriotic cysts forming a tumor mass in the ovaries; these cysts contain liquid and present dark brown color similar to chocolate $[21,22]$. For many years, the ultrasound diagnosis of endometriosis was only conducted in patients presenting evident endometriomas [6]. However, nowadays, it is well known that endometriosis also affects other regions in the pelvis such as the intestine, mainly the rectosigmoid region $[8,12]$.

The gravitational effect may justify the larger number of lesions recorded in the pelvic compartment in comparison with abdomen; this happens because intestinal lesions are preferentially located in the rectum and in the rectosigmoid region [23]. Similar to the present study, previous studies [18, 24, 25] often found endometriosis in the rectosigmoid region. Guerriero et al. [12] found that TVUS is an accurate method to diagnose endometriosis in the rectosigmoid region and may be adopted in preoperative assessments.

Endometriosis is associated with women's reproductive period, although it has been reported at earlier ages [26]. In this study, women with endometriosis was significantly older than those whose TVUS results did not suggest the disease. The mean age of women with ultrasound signs of endometriosis 
(37.16 years) was also significantly higher than the mean age recorded in other studies, such as that conducted by Holland et al. [27], in which women with clinical suspicion of the disease had a mean age of 35.0 years; and that conducted by Bellelis et al. [16], in which patients with endometriosis had a mean age of 33.2 years.

A significantly higher proportion of women presenting long-lasting symptoms was also recorded among patients whose TVUS suggested endometriosis. It takes long (from 4 to 10 years) since the onset of symptoms until the disease is diagnosed [28]; such delay highlights the importance of preventive actions towards adolescents in order not to compromise their reproductive future [1].

The current study recorded a significantly higher proportion of women presenting higher mean CA-125 value among those with ultrasound findings of endometriosis. A systematic review found that CA-125 serum levels equal to or higher than $30 \mathrm{U} / \mathrm{ml}$ had high specificity (93.0\%; 95\% confidence interval 89-95\%) but low sensibility $(52 \%$; $95 \%$ confidence interval $38-66 \%$ ) in the diagnosis of endometriosis in symptomatic women [29].

In more specific situations, such as preoperative planning, CA-125 serum levels higher than $35 \mathrm{U} / \mathrm{ml}$ are related to high frequency of ovarian endometriomas. In the lack of ovarian endometriomas, CA-125 levels higher than $35 \mathrm{U} / \mathrm{ml}$ suggest a 3.2 times higher probability of patients to develop deep infiltrating endometriosis [30].

On the other hand, ultrasound findings indicating endometriosis did not show association with marital status, schooling, parturiency, family history or knowledge about the disease. Nevertheless, it is worth highlighting that endometriosis was more often diagnosed in married women, in the study of Doniatti [31]. The results recorded in that study might be justified by family planning, since those women wanted to get pregnant; this desire was associated with factors such as financial stability, academic and professional success, and little knowledge about the disease [32].

According to Holland et al. [27], previous knowledge about the extent of the disease and its location helps improving the preoperative planning, as well as developing personalized treatments. Thus, it enables the excision of symptomatic lesions and avoids the adoption of complex procedures to remove asymptomatic lesions from anatomical sites difficult to be located. It is worth emphasizing that the TVUS is an operator-dependent technique, as well as that a single TVUS operator performed the examinations in the current study. Moreover, it was recently demonstrated that examiners who are familiar with the procedure may achieve proficiency in the diagnosis of deep endometriosis after conducting forty examinations [32]. Therefore, the professional who performed the ultrasound examinations in the current study was a specialist in the field and had a two-year experience in investigating endometriosis through TVUS (which assured the reliability of the procedure).

A limitation of the current study lies on the lack of follow-up of many patients, avoiding diagnostic confirmation through videolaparoscopy and histological analysis. This happened because many attending physicians did not choose such procedure based on the clinical history of the patients. Despite this limitation, we can conclude that TVUS confirmed endometriosis in about one third of symptomatic patients, who were older, had symptoms for a longer time, and had a higher serum CA-125 antigen level in comparison to those who did not have endometriosis diagnosis based on TVUS. Ovaries and rectosigmoid region were the sites with the highest frequency of ultrasound signs of endometriosis.

\section{NOTES}

Funding

This study did not receive financial support from outside sources.

Conflicts of interest disclosure

The authors declare no competing interests relevant to the content of this study.

\section{Authors' contributions}

All the authors declare to have made substantial contributions to the conception, or design, or acquisition, or analysis, or interpretation of data; and drafting the work or revising it critically for important intellectual content; and to approve the version to be published.

Availability of data and responsibility for the results

All the authors declare to have had full access to the available data and they assume full responsibility for the integrity of these results. 


\section{REFERENCES}

1. Febrasgo. Federação Brasileira das Associações de Ginecologia e Obstetrícia. Manual de endometriose. São Paulo: Febrasgo; 2015.

2. Saccardi C, Cosmi E, Borghero A, Tregnaghi A, Dessole S, Litta P. Comparison between transvaginal sonography, saline contrast sonovaginography and magnetic resonance imaging in the diagnosis of posterior deep infiltrating endometriosis. Ultrasound Obstet Gynecol. 2012;40:464-9. https://doi.org/10.1002/uog.11102

3. Santos, TMV, Pereira AMG, Lopes RGC, Depez DB. Tempo transcorrido entre o início dos sintomas e o diagnóstico de endometriose. Einstein. 2012;10(1):39-43. https://doi.org/10.1590/S1679-45082012000100009

4. Nacul AP, Spritzer PM. Aspectos atuais do diagnóstico e tratamento da endometriose. Rev Bras Ginecol Obstet. 2010;32(6):298-307. https://doi.org/10.1590/S0100-72032010000600008

5. Noventa M, Saccardi C, Litta P. Ultrasound techniques in the diagnosis of deep pelvic endometriosis: algorithm based on a systematic review and meta-analysis. Fertil Steril. 2015;104(2):366-83. https://doi.org/10.1016/j.fertnstert.2015. 05.002

6. Benacerraf BR, Groszmann Y. Sonography Should Be the First Imaging Examination Done to Evaluate Patients With Suspected Endometriosis. J Ultrasound Med. 2012;31:651-3. https://doi.org/10.7863/jum.2012.31.4.651

7. Guerriero S, Ajossa S, Minguez JA, Jurado M, Mais V, Melis GB, Alcazar JL. Accuracy of transvaginal ultrasound for diagnosis of deep endometriosis in uterosacral ligaments, rectovaginal septum, vagina and bladder: systematic review and meta-analysis. Ultrasound Obstet Gynecol. 2015;46(5):534-45. https://doi.org/10.1002/uog.15667

8. Arruda MS, Camargo MMA, Camargo Jr. HSA, Teixeira SRC. Endometriose profunda: aspectos ecográficos. Femina. 2010;38(7):367-72.

9. Hudelist G, Ballard K, English J, Wright J, Banerjee S, Mastoroudes H, Thomas A, Singer CF, Keckstein J.Transvaginal sonography vs. clinical examination in the preoperative diagnosis of deep infiltrating endometriosis. Ultrasound Obstet Gynecol. 2011;37(4):480-7. https://doi.org/10.1002/uog.8935

10. Acimovic M, Vidakovic S, Milic N, Jeremic K, Markovic M, Milosevic-Djeric A, Lazovic-Radonjic G. Survivin and vegf as novel biomarkers in diagnosis of endometriosis. J Med Biochem. 2015;35(1):63-8. https://doi.org/10.1515/jomb2015-0005

11. IBGE. Instituto Brasileiro de Geografia e Estatística. Panorama: Ijuí, Rio Grande do Sul, Brasil. 2018 [cited 2018 October 30]. Available from: https://cidades.ibge.gov.br/brasil/rs/ijui/panorama

12. Guerriero S, Condous G, van den Bosch T, Valentin L, Leone FP, Van Schoubroeck D, Exacoustos C, Installé AJ, Martins WP, Abrao MS, Hudelist G, Bazot M, Alcazar JL, Gonçalves MO, Pascual MA, Ajossa S, Savelli L, Dunham R, Reid S, Menakaya U, Bourne T, Ferrero S, Leon M, Bignardi T, Holland T, Jurkovic D, Benacerraf B, Osuga Y, Somigliana E, Timmerman D. Systematic approach to sonographic evaluation of the pelvis in women with suspected endometriosis, including terms, definitions and measurements: a consensus opinion from the International Deep Endometriosis Analysis (IDEA) group. Ultrasound Obstet Gynecol. 2016;48:318-32. https://doi.org/10.1002/uog.15955

13. Guerriero S, Ajossa S, Gerada M, Virgilio B, Angioni S, Benedetto GM. Diagnostic value of transvaginal 'tendernessguided' ultrasonography for the prediction of location of deep endometriosis. Human Reproduction. 2008;11:2452-7. https://doi.org/10.1093/humrep/den293

14. Ferrero S, Arena E, Morando A, Remorgida V. Prevalence of newly diagnosed endometriosis in women attending the general practitioner. Int J Gynaecol Obstet. 2010;110:203-7. https://doi.org/10.1016/j.ijgo.2010.03.039

15. Bazot M, Lafont C, Rouzier R, Roseau G, Thomassin-Naggara I, Daraï E. Diagnostic accuracy of physical examination, transvaginal sonography, rectal endoscopic sonography, and magnetic resonance imaging to diagnose deep infiltrating endometriosis. Fertil Steril. 2009;92(6):1825-33. https://doi.org/10.1016/j.fertnstert.2008.09.005

16. Bellelis P, Dias Jr JA, Podgaec S, Gonzales M, Baracat EC, Abrão MS.Aspectos epidemiológicos e clínicos da endometriose pélvica - uma série de casos. Rev Assoc Med Bras. 2010;56(4):467-71. https://doi.org/10.1590/S010442302010000400022

17. Hernández AG, Rechy GO, García EG. Factores de riesgo asociados, métodos diagnósticos y tratamiento para endometriosis, utilizados en la clínica de endometriosis del servicio de Ginecología del Hospital General de México (2009- 2011). Ginecol Obstet Mex. 2012;80(10):637-43.

18. Piketty M, Chopin N, Dousset B, Millischer-Bellaische AE, Roseau G, Laconte M, Borghese B, Chapron C. Preoperative work-up for patients with deeply infiltrating endometriosis: transvaginal ultrasonography must definitely be the first-line imaging examination. Hum Reprod. 2009;24(3):602-7. https://doi.org/10.1093/humrep/den405

19. Cardoso EPS, Anselmo NM, Miguel KJ, Silva ABC. Endometriose em diferentes faixas etárias: perspectivas atuais no diagnóstico e tratamento da doença. Ciência et Praxis. 2011;4(8):53-8.

20. Goncalves MO, Podgaec S, Dias JA Jr, Gonzalez M, Abrao MS. Transvaginal ultrasonography with bowel preparation is able to predict the number of lesions and rectosigmoid layers affected in cases of deep endometriosis, defining surgical strategy. Hum Reprod. 2010;25(3):665-71. https://doi.org/10.1093/humrep/dep433

21. Nominato NS, Prates LFVS, Lauar I, Morais J, Maia L, Geber S. Endometriose de cicatriz cirúrgica: Estudo retrospectivo de 25 anos. Rev Bras Ginecol Obstet. 2007;29(8):403-7. https://doi.org/10.1590/S0100-72032007000800007

22. Berek JS. Tratado de Ginecologia. 14aㅡ ed. Rio de Janeiro: Guanabara Koogan; 2008. 
23. Chapron C, Chopin N, Borghese B, Foulot H, Dousset B, Vacher-Lavenu MC, Vieira M, Hasan W, Bricou A. Deeply infiltrating endometriosis: pathogenetic implications of the anatomical distribution. Hum Reprod. 2006;21(7):1839-45. https://doi.org/10.1093/humrep/del079

24. Cardoso MM, Junior HW, Berardo PT, Coutinho Junior AC, Domingues MNA, Gasparetto EL, Domingues RC. Avaliação da concordância entre a ultrassonografia transvaginal e a ressonância magnética da pelve na endometriose profunda, com ênfase para o comprometimento intestinal. Radiol Bras. 2009;42(2):89-95. https://doi.org/10.1590/S010039842009000200006

25. Massein A, Petit E, Darchen MA, Loriau J, Oberlin O, Marty O, Sauvanet E, Afriat R, Girard F, Molinié V, Duchatelle V, Zins M. Imaging of intestinal involvement in endometriosis. Diagn Interv Imaging. 2013;94(3):281-91. https://doi. org/10.1016/j.diii.2012.11.003

26. Stuparich MA, Donnellan NM, Sanfilippo JS. Endometriosis in the Adolescent Patient. Semin Reprod Med. 2017;35(1): 102-9.

27. Holland TK, Cutner A, Saridogan E, Mavrelos D, Pateman K, Jurkovic D. Ultrasound mapping of pelvic endometriosis: does the location and number of lesions affect the diagnostic accuracy? a multicentre diagnostic accuracy study. MC Womens Health. 2013;13:43. https://doi.org/10.1186/1472-6874-13-43

28. Dunselman GAJ, Vermeulen N, Becker C, Calhaz-Jorge C, D’Hooghe T, De Bie B, Heikinheimo O, Horne AW, Kiesel L, Nap A, Prentice A, Saridogan E, Soriano D, Nelen W; European Society of Human Reproduction and Embryology. ESHRE guideline: management of women with endometriosis. Hum Reprod. 2014;29(3):400-12. https://doi.org/10.1093/ humrep/det457

29. Hirsch M, Duffy J, Davis CJ, Nieves Plana M, Khan KS; International Collaboration to Harmonise Outcomes and Measures for Endometriosis. Diagnostic accuracy of cancer antigen 125 for endometriosis: a systematic review and meta-analysis. BJOG. 2016;123(11):1761-8. https://doi.org/10.1111/1471-0528.14055

30. Zomer MT, Ribeiro R, Trippia CH, Cavalcanti TCS, Hayashi RM, Kondo W. Correlação entre os níveis de Ca-125 séricos e os achados cirúrgicos em mulheres com sintomas sugestivos de endometriose. Rev Bras Ginecol Obstet. 2013;35(6): 262-7. https://doi.org/10.1590/S0100-72032013000600005

31. Doniatti, L. Endometriose, um estudo correlacional: estratégias de enfrentamento (coping) depressão, estresse e dor [dissertation]. [São Paulo]: Pontifícia Universidade Católica de São Paulo; 2014. Available from: https://tede2.pucsp. $\mathrm{br} / \mathrm{handle} / \mathrm{handle} / 15390$

32. Piessens S, Healey M, Maher P, Tsaltas J, Rombauts L. Can anyone screen for deep infiltrating endometriosis with transvaginal ultrasound? Aust N Z J Obstet Gynaecol. 2014;54:462-8. https://doi.org/10.1111/ajo.12242 